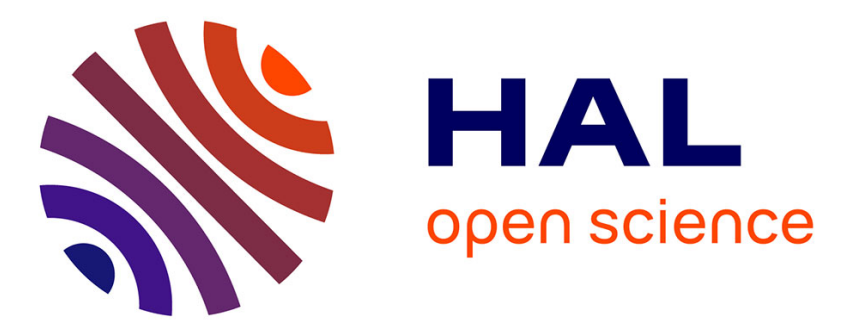

\title{
Plutonic processes in transitional oceanic plateau crust: Structure, age and emplacement of the South Rallier du Baty laccolith, Kerguelen Islands
}

Léandre Ponthus, Michel de Saint Blanquat, Damien Guillaume, Marc Le Romancer, Norman Pearson, Suzanne O'Reilly, Michel Grégoire

\section{To cite this version:}

Léandre Ponthus, Michel de Saint Blanquat, Damien Guillaume, Marc Le Romancer, Norman Pearson, et al.. Plutonic processes in transitional oceanic plateau crust: Structure, age and emplacement of the South Rallier du Baty laccolith, Kerguelen Islands. Terra Nova, 2020, 32 (6), pp.408-414. 10.1111/ter.12471 . hal-03024359

\section{HAL Id: hal-03024359 \\ https://hal.science/hal-03024359}

Submitted on 25 Nov 2020

HAL is a multi-disciplinary open access archive for the deposit and dissemination of scientific research documents, whether they are published or not. The documents may come from teaching and research institutions in France or abroad, or from public or private research centers.
L'archive ouverte pluridisciplinaire HAL, est destinée au dépôt et à la diffusion de documents scientifiques de niveau recherche, publiés ou non, émanant des établissements d'enseignement et de recherche français ou étrangers, des laboratoires publics ou privés. 


\section{Plutonic processes in transitional oceanic plateau crust: Structure, age and emplacement of the South Rallier du Baty laccolith, Kerguelen Islands}

Léandre Ponthus, | Michel de Saint Blanquat, Damien Guillaume, Marc Le Romancer, Norman Pearson, Suzanne O’Reilly, Michel Grégoire, Michel de Saint Blanquat

\section{To cite this version:}

Léandre Ponthus, | Michel de Saint Blanquat, Damien Guillaume, Marc Le Romancer, Norman Pearson, et al.. Plutonic processes in transitional oceanic plateau crust: Structure, age and emplacement of the South Rallier du Baty laccolith, Kerguelen Islands. Terra Nova, Wiley-Blackwell, 2020, 10.1111/ter.12471 . hal-03024359

\section{HAL Id: hal-03024359 \\ https: / hal.archives-ouvertes.fr/hal-03024359}

Submitted on 25 Nov 2020

HAL is a multi-disciplinary open access archive for the deposit and dissemination of scientific research documents, whether they are published or not. The documents may come from teaching and research institutions in France or abroad, or from public or private research centers.
L'archive ouverte pluridisciplinaire HAL, est destinée au dépôt et à la diffusion de documents scientifiques de niveau recherche, publiés ou non, émanant des établissements d'enseignement et de recherche français ou étrangers, des laboratoires publics ou privés. 


\title{
Plutonic processes in transitional oceanic plateau crust: Structure, age and emplacement of the South Rallier du Baty laccolith, Kerguelen Islands
}

\author{
Léandre Ponthus $^{1}$ | Michel de Saint Blanquat ${ }^{1}$ (D) | Damien Guillaume ${ }^{2}$ | \\ Marc Le Romancer $^{3}$ | Norman Pearson ${ }^{4}$ | Suzanne O'Reilly ${ }^{4}$ | Michel Grégoire ${ }^{1}$ (D)
}

${ }^{1}$ Géosciences Environnement Toulouse, Université de Toulouse, CNES, CNRS, IRD, UPS, Toulouse, France

${ }^{2}$ Univ Lyon, UJM-Saint-Etienne, CNRS, LMV UMR 6524, Saint-Etienne, France

${ }^{3}$ EA7462 Geoarchitecture, Université de Bretagne Occidentale, Brest, France

${ }^{4}$ ARC Centre of Excellence for Core to Crust Fluid Systems and GEMOC, Department of Earth and Planetary Sciences, Macquarie University, Sydney, NSW, Australia

\section{Correspondence}

Michel de Saint Blanquat, Géosciences Environnement Toulouse, Université de Toulouse, CNES, CNRS, IRD, UPS, Toulouse, France.

Email: michel.desaintblanquat@get.omp.eu

Funding information

Institut Polaire Français Paul Emile Victor;

Centre National de la Recherche Scientifique

\begin{abstract}
The syenitic rocks of South Rallier du Baty Intrusive Complex (SRBIC) represent intrusions into the oceanic plateau basalts of the south-western Kerguelen Islands. The SRBIC was previously interpreted as a typical ring complex due to magma emplacement with cauldron subsidence. Our new structural and geochronological data reveal that it is a laccolith built between 11.6 and $7.9 \mathrm{Ma}$ by successive injections of magma sheets around the crust-mantle boundary, with an average injection rate between 0.8 and $1.4 \times 10^{-4} \mathrm{~km}^{3} /$ year. These results establish strong similarities between the SRBIC, the only recorded example of a felsic laccolith in an oceanic intraplate setting, and many continental plutons emplaced in various geodynamic setting. The SRBIC thus has the characteristics of a continental plutonic complex emplaced in an oceanic plateau crust. We postulate the critical parameter relevant to causing such similarities and plutonic magmatism is crustal thickness.
\end{abstract}

\section{KEYWORDS}

alkaline magmatism, Kerguelen, oceanic plateau, pluton emplacement, syenite intrusion

\section{1 | INTRODUCTION}

The main output of Earth magmatic activity is represented by intrusive rocks (Crisp, 1984; Paterson \& Ducea, 2015; Shaw, 1985; White, Crisp, \& Spera, 2006). Within oceanic crust, accretionary processes by injection of mainly mafic (gabbro sensu lato) magmas are highly sensitive to the spreading rate (Dick, Natland, \& ODP leg 176 Scientific Team, 2000). Observation of layered complexes and/or gabbroic bodies in the lower part of oceanic crust in fast- and slow-spreading contexts suggests multiple mechanisms of crustal accretion and melt differentiation (Cannat, 1996; Dick, Tivey, \& Tucholke, 2008; Gillis et al., 2014; Ildefonse et al., 2007). However, there are very few observations about the characteristics of magma emplacement, including the size/volume of individual injection, and the temporal and spatial relationships of successive injections.
Within continental crust, intrusive rocks occur mainly as plutons, that is, magmatic bodies of varying size, shape and composition, but generally corresponding to a single magmatic event. Recent studies showed that continental plutons, from all crustal depths, are mainly tabular, displace their wallrocks and originate by localized injections of discrete magma pulses over variable periods of time (Annen, Blundy, Leuthold, \& Sparks, 2015; Coleman, Mills, \& Zimmerer, 2016; Cruden, 1998; de Saint-Blanquat, Law, Bouchez, \& Morgan, 2001; Farina, Dini, Innocenti, Rocchi, \& Westerman, 2010; Glazner, Bartley, Coleman, Gray, \& Taylor, 2004; Horsman et al., 2009; Leuthold et al., 2012; Petford, Cruden, McCaffrey, \& Vigneresse, 2000; among many others). Underlying the concept of plutons is the observation of focused emplacement of magma, that is the existence of a "close in space-close in time" relationship (de Saint-Blanquat et al., 2011).

One of the main remaining questions about earth magmatism in both oceanic and continental domains is the role(s) of the crustal 
"filter" (including thickness, composition, rheological stratification and structure) in magma production, differentiation, contamination, transport and final emplacement style and geometry. This question can be explored by characterizing and comparing the structure and detailed construction of plutons in different geodynamic settings. Although there are numerous existing datasets for continental plutons, there are very few that address a detailed understanding of the structure and detailed geochronology of oceanic plutons. We therefore focused this study on the South Rallier du Baty Intrusive Complex (SRBIC) outcropping in the south-western part of the Kerguelen Islands within a thick oceanic plateau crust. This plutonic complex is the most spectacular known occurrence of felsic oceanic plutonic rocks and, along with the intrusive complexes from Iceland (Burchardt, Tanner, \& Krumbholz, 2010; Padilla et al., 2016), represents the only example of outcropping felsic plutonic rocks in an oceanic contexts as other occurrences are only inferred from xenoliths in the Azores and Ascension islands (Kar, Weaver, Davidson, \& Colucci, 1998; Widom, Gill, \& Schmincke, 1993). Therefore, the SRBIC is an ideal target to obtain precise quantitative data (internal structure, geometry, duration of emplacement) on the construction of a pluton in an oceanic domain, and thus allows a comparison between oceanic and continental plutonic processes. Moreover, previous studies already questioned the oceanic/continental/transitional nature of the northern Kerguelen plateau crust considering its geodynamic setting (Grégoire, Cottin, Giret, Mattielli, \& Weis, 1998; Watkins, Gunn, Nougier, \& Baksi, 1974). We present in this study new constraints for the construction of the SRBIC based on a set of new field structural observations, accompanied by detailed $\mathrm{U}-\mathrm{Pb}$ geochronological data.

\section{2 | GEOLOGICAL CONTEXT AND PREVIOUS STUDIES}

The Kerguelen Islands represent the emergent part of the Northern Kerguelen oceanic Plateau (NKP), assumed to be formed by activity of the Kerguelen plume (Gautier et al., 1990; Watkins et al., 1974). These islands primarily consist of tholeiitic to transitional basalt flows emplaced from $\sim 29$ to $\sim 24 \mathrm{Ma}$ (Figure S1; Table S1). Several volcano-plutonic complexes emplaced into this basalt sequence are distributed through the islands and range in age from $\sim 24$ to $\sim 4.9 \mathrm{Ma}$ (Figure S1; Table S1). With the exception of the oldest tholeiitic-transitional gabbroic complexes, all the younger differentiated intrusive complexes show a bimodal composition with either Si-oversaturated or Si-undersaturated alkaline rock series. The SRBIC is part of a $\sim 350 \mathrm{~km}^{2}$ plutonic province (Nougier, 1969; Figure 1; Figure S1). The plutonic rocks of the SRBIC belong to the Si-oversaturated series and range from monzogabbros and monzodiorites to mostly quartzmonzonites and syenites. Rare mafic and intermediate intrusive coarse-grained rocks are only associated with the syenites in the external parts of the SRBIC. The ages obtained for syenites by previous authors with the $\mathrm{K}-\mathrm{Ar}$ and $\mathrm{Rb}-\mathrm{Sr}$ whole rock methods range between $\sim 15.5$ and $\sim 7.5 \mathrm{Ma}$ from the south to the north of the SRBIC (Table
S1). Geophysical studies revealed an abnormally thick crust beneath the NKP with a total crustal thickness estimated to range from 20 to $25 \mathrm{~km}$ (Charvis, Recq, Operto, \& Brefort, 1995). Based on the study of oceanic mafic granulite xenoliths, Grégoire et al. (1994), Grégoire et al. (1998) related the deep seismic properties to underplating processes of basaltic melts and associated cumulates equilibrated in the granulites facies, resulting in a transitional and thick crust-mantle boundary. The SRBIC has been considered in early studies as a ring complex and a typical example of emplacement by cauldron subsidence (Bonin et al., 2004; Giret, 1983).

\section{3 | GEOMETRY OF THE SRBIC}

The SRBIC intrudes the plateau lavas and forms a $17 \times 11 \mathrm{~km}$ elliptical body with a WSW-ENE long axis (Figure 1). The contact between the intrusion and the basalts shows two contrasting geometries (Figure 2 and Figure S2): (a) steeply dipping and cross-cutting or (b) shallowly dipping and concordant. At the scale of the Kerguelen Islands, the orientation of the basaltic lava flows is very regular with a small $\operatorname{dip}\left(2-5^{\circ}\right)$ towards the SE, ascribed to recent tilting (Nougier, 1969; Figure S1). This orientation changes towards the intrusive centres, particularly when approaching the SRBIC. Indeed, progressive tilting of the flood basalts is observed all around the NE, SE and SW parts of the SRBIC, reaching a dip of $20-40^{\circ}$ away from the intrusion (Figures 1 and 2; Figures S1 and S2). Because of recent volcanic activity and ice cover, this contact is not exposed in the NW part of the complex. Nevertheless, measurements of the basalt flows layering along the coast on the western side of the SRBIC dips towards the W. Measurements of primary layering all around the SRBIC confirm that the basalts are tilted away from the intrusive centre with dip increasing towards the contact, a feature already documented by Nougier (1969). The floor and the roof of the SRBIC are not exposed, but the geometry of the surrounding basalt lava flows, the amplitude of their flexure towards the intrusive centre and the location of this flexure, allow us to draw a precise cross-section which indicates that the base of the SRBIC lies at a depth of $\sim 2 \mathrm{~km}$. As the highest syenitic outcrops are at an altitude of $\sim 600 \mathrm{~m}$, we infer that the SRBIC could be modelled as a tabular elliptical magmatic body with a thickness of 2-3 km, a $20 \mathrm{~km}$ WSW-ENE long axis and a $16 \mathrm{~km} \mathrm{NNW-SSE} \mathrm{short}$ axis at its base. From these geometrical observations, its volume can be estimated at about $\sim 400 \mathrm{~km}^{3} \pm 100 \mathrm{~km}^{3}$.

\section{4 | INTERNAL STRUCTURE}

Three main syenitic units separated by sharp magmatic contacts can be distinguished in the field (Figures 1 and 2; Figure S3). Unit 1 occurs along the intrusion margin, Unit 3 at its centre and Unit 2 lies between the two. Field observations indicate that these units are younger towards the centre of the intrusive complex. Each unit consists of several layered intrusions with contrasting textures. All the textures and contacts are magmatic. These different injections of 


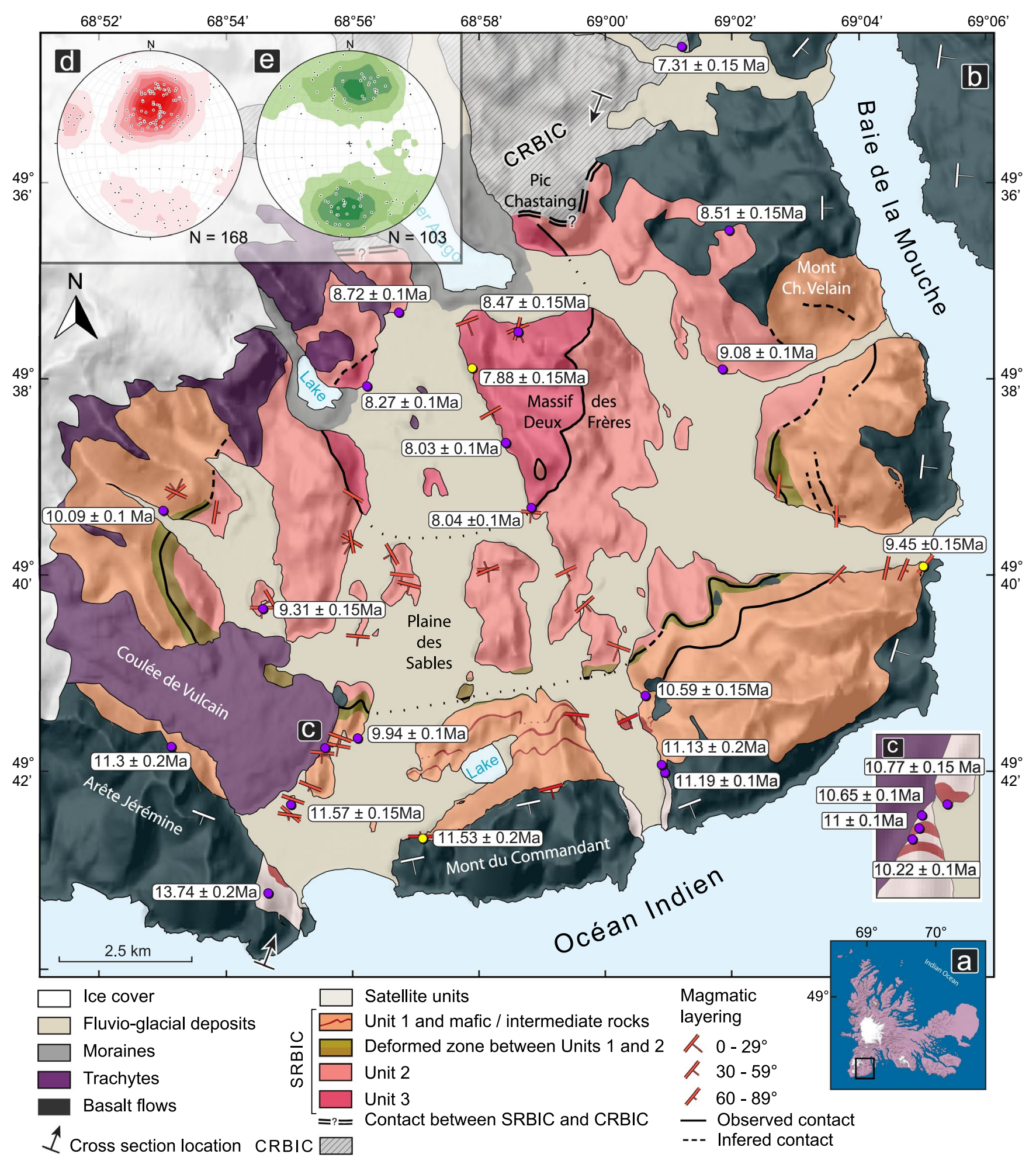

FIGURE 1 (a) Location of the South Rallier du Baty Intrusive Complex, (b) Structural map of the SRBIC with simplified geology and geochronological data acquired on single zircons (purple circles) and thick sections (yellow circles). (c) Detailed map of a small area with closely spaced U-Pb geochronology sample sites. Equal area, lower hemisphere stereographic projection of poles to magmatic layering (d) and cataclastic shear zones (e); arrows indicate the location of the cross-section in the Figure 2. CRBIC and SRBIC: Central and South Rallier du Baty Intrusive Complexes

mainly coarse and fine-grained syenites, pegmatites and rare monzodiorites, define a magmatic layering (Figures 1d, 2 and 3) which dips consistently outward across the SRBIC, and decreases towards the centre of the intrusion. Moreover, this general magmatic layering is parallel to the external contact with basalts and is also parallel to the main internal contacts that separate the three main syenitic units 


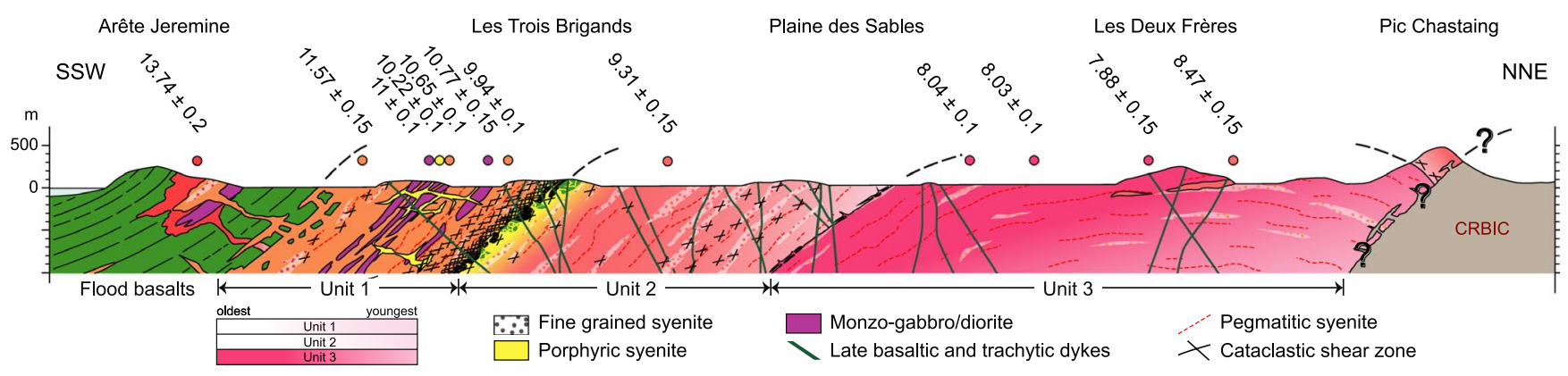

FIGURE 2 SSW-NNE geological cross-section of the SRBIC drawn from field relations. U-Pb results of samples located along or at a distance lower than $2 \mathrm{~km}$ of the cross-section are showed; the colour of the small coloured circle corresponds to the sample lithology

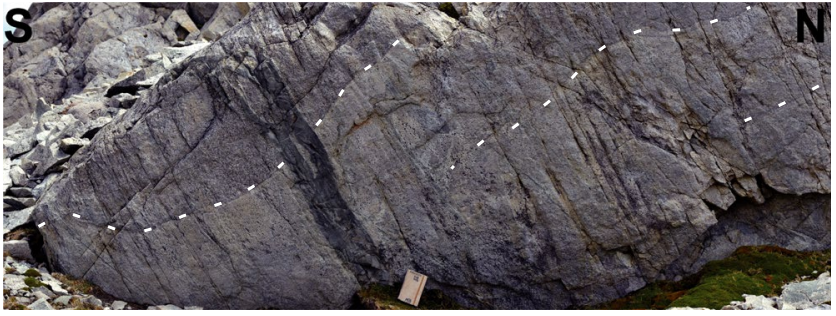

FIGURE 3 Field example of a south-dipping magmatic contact underlined by a dashed white line between two syenitic layers of contrasted magmatic textures. Both layers are cross-cut by basaltic dykes dipping to the N. Central part of the Unit 2

(Figures 1 and 2; Figure S4a). The textures are magmatic throughout the SRBIC; preferred orientation fabrics are poorly developed and rarely visible in the field.

A network of brittle-ductile shear zones is observed throughout the intrusion, except in the youngest Unit 3. They are interpreted to be syn-plutonic as evidenced by mutual cross-cutting relationships between shear zones and dyke intrusions (Figure S5). Their distribution is heterogeneous and shows a denser network at the base of Unit 1 at its contact with the underlying Unit 2 (Figure 2; Figure S4b). The orientation of this network and the observed senses of shear suggest that the shear zones are the result of a shortening perpendicular to the contact between these two units. This defines a ring of more deformed and brecciated syenites (Figure 1), which records flattening of the marginal unit due to injection of the lower units. These features imply an advanced crystallization stage of the older unit before intrusion of the younger one.

\section{5 | NEW GEOCHRONOLOGICAL DATA}

The methodology, sample location and raw data are available in the Supporting Information (Figures S6 and S7; Tables S2-S4). Most zircons from the SRBIC rocks exhibit a characteristic morphology with (100) prisms and (101) pyramids as well as clear oscillatory and sector zonings (Figure S6). The oldest syenite (13.74 $\pm 0.2 \mathrm{Ma}$ ) was sampled in the southern part of the peninsula and is from one of the first emplaced minor complex clearly disconnected in space and time from the SRBIC (Figures 1 and 2; Figure S7). If we interpret $\mathrm{U}-\mathrm{Pb}$ zircon ages as maximum emplacement ages, the major volume of SRBIC magma was emplaced between $11.57 \pm 0.15$ and $7.88 \pm 0.2 \mathrm{Ma}$. The zircon ages of the monzodiorites are similar to those of surrounding syenites, suggesting synchronous emplacement of magmas with contrasting degrees of differentiation. U-Pb zircon ages show that the syenites become younger towards the centre of the intrusive complex, from the marginal Unit 1 to the central Unit 3, in agreement with field observations (Ponthus, 2018; Figures 1 and 2).

\section{6 | DISCUSSION AND CONCLUSION}

The SRBIC was previously interpreted as a ring complex emplaced by cauldron subsidence that corresponds to a cluster of intersecting ring dykes injected during down-sagging of a crustal block into a deeper magma chamber, and overlain by a caldera (Bonin et al., 2004; Giret, 1983). Based on our new field and geochronological data, we propose a new model of construction for the SRBIC based on the following main features:

1. The consistent spatial coincidence between the change in the orientation of layering in the surrounding basalts and the external contacts of the SRBIC indicates a causal relationship, which suggests that the main space-making process for the emplacement of magmas was uplift and up-doming of host basalts. This feature was already recorded by previous authors (Nougier, 1969) and interpreted as being due to the formation of deep lower crustal magma chambers before (Giret, 1983) or during (Bonin et al., 2004) the formation of the SRBIC. These interpretations are not consistent with field observations, as the uplift produced by deep magma chambers should be more randomly distributed, rather than coinciding exactly with the intrusion geometry. The deflection of the plateau basalts suggests that the SRBIC has a dome shape and is concordant at map scale, which is consistent with emplacement as a laccolith (Figure 4). The discordant and steeply dipping parts of the external contact are irregularities due to local stoping, as suggested by the occurrence of basalt screens within the syenite below those parts of the contact, and/or as extensional 


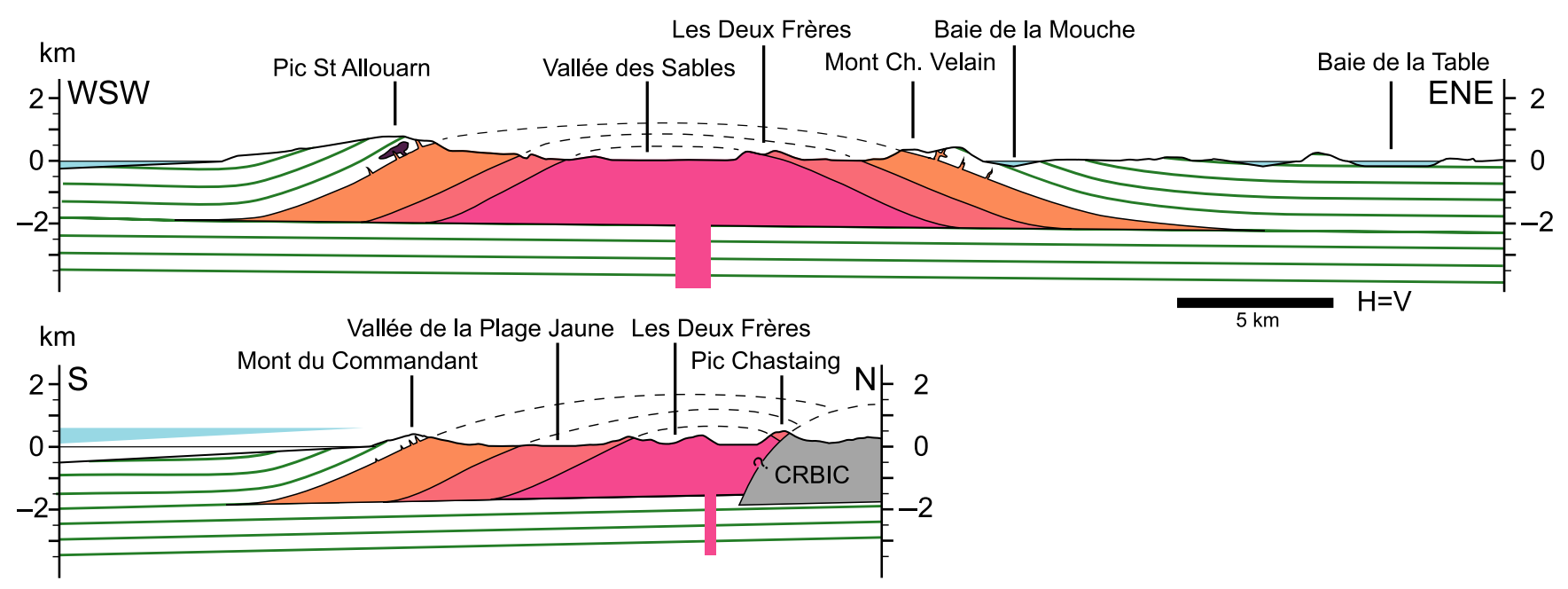

FIGURE 4 Interpreted cross-sections of the general laccolithic geometry of the SRBIC along two sub-perpendicular cross-sections. The representation of the contact between the SRBIC and the CRBIC is conjectural

fractures filled by magma and related to the extensional component of strain in the wall rocks induced by magma infilling.

2. The internal structure shows that each of the three main units of magma comprises numerous injections of syenite, with rare monzodiorite in the oldest unit. The magmatic layering is concentric and concordant within and between each unit from external contact to the centre of the intrusive complex. This layering dips towards the outside margin of the complex, decreasing from the periphery towards the centre of the SRBIC. The sharp contacts between the three main syenitic units and the brittle deformation of the two older units demonstrate that in spite of an apparent $\mathrm{N}-\mathrm{S}$ continuous age distribution, the construction of the SRBIC was discontinuous. The textural difference observed between the coarse and fine-grained syenites was acquired during the emplacement process and we interpret it as the record of the dynamics of magma injection: different volumes of magma injected at variable rates and after variable time intervals between injections will have varying temperature contrasts with previous injections and consequently different cooling rates and thus textures. The two other main facies, the pegmatites and the network of porphyritic syenites, are inferred to have been produced by local mechanical segregation in an older, incompletely crystallized injection during the injection of a younger one. Field relationships and geochronology demonstrate that the SRBIC was constructed by the amalgamation of successive under-accreted magma injections.

3. The field relationships and $\mathrm{U}-\mathrm{Pb}$ geochronology both provide evidence that the magmatic injections become progressively younger towards the centre of the SRBIC. The U-Pb data indicate that the construction of the SRBIC lasted approximately $3.7 \mathrm{Ma}$, between $11.57 \pm 0.15$ and $7.88 \pm 0.2 \mathrm{Ma}$. With a total estimated volume of about $300-500 \mathrm{~km}^{3}$, this suggests an average injection rate between 0.8 and $1.4 \times 10^{-4} \mathrm{~km}^{3} /$ year.

In summary, our data are compatible with a model where the SRBIC is an incrementally assembled laccolith constructed by the upward inflation (evidenced by basalt uplift) and stacking (evidenced by the internal structure) of initially horizontal thin magma sheets. Our results establish strong similarities between the SRBIC-a unique example of a felsic laccolith in an oceanic within-plate setting-and continental plutons. First, the 3D geometry, internal structure and emplacement mechanism of the SRBIC are identical to many continental examples. Second, from a dynamic and temporal perspective, it appears that the duration and the average magma flux during SRBIC construction are similar to those proposed for many continental plutons located in contrasting geodynamic settings (Rocchi, Westerman, Dini, Innocenti, \& Tonarini, 2002; de SaintBlanquat et al., 2011 and references therein; Barboni et al., 2013; Barboni, Annen, \& Schoene, 2015; Coleman et al., 2016; Leuthold et al., 2012; and references therein).

In analysing similarities between magma emplacement in the Kerguelen plateau oceanic crust and the continental crust, and comparing it with the structure of the standard oceanic crust, we postulate that crustal thickness is the critical parameter that controls the intrusion characteristics. A thick oceanic crust associated with a progressive lithological transition between mantle and crust will favour the formation of a zone where the accumulation and differentiation of magma occur at the crust-mantle boundary, in the manner of MASH/Deep hot zone area of the continental crust (Annen, Blundy, \& Sparks, 2006; Hildreth \& Moorbath, 1988). Magma evolution in the "oceanic MASH/ Deep hot zone" from Kerguelen certainly plays the major role, by providing variable volumes of magma at variable timescales, resulting in a final magmatic output forming plutons (Ponthus, 2018). This latter permits to localize injections of magma in close space and time, rather than producing spatially and temporally dispersed network of veins, sills and dykes.

The new ideas we propose on how plutonic processes work in the Kerguelen oceanic plateau have implications on the general interpretation of alkaline magmatism in this context, particularly in the light of the comparison made by Grégoire et al. (1998) between the thickened Kerguelen oceanic lithosphere and the thinned 
continental lithosphere based on the study of mafic granulitic xenoliths from the Kerguelen Islands.

\section{ACKNOWLEDGEMENTS}

We thank the French Polar Institute Paul-Emile Victor (IPEVTALISKER 1077 program, D. Guillaume; IPEV-DYLIOKER 444 program, B.N. Moine), Y. Le Meur and the IPEV-logistic staff for field assistance and support. We also thank the CNRS-INSU, OMP and the GET for funding allowing data acquisitions. This is contribution 1499 from the ARC Centre of Excellence for Core to Crust Fluid Systems (http://www.ccfs.mq.edu.au) and 1384 from the GEMOC Key Centre (http://www.gemoc.mq.edu.au). The analytical data were obtained using instrumentation funded by DEST Systemic Infrastructure Grants, ARC LIEF, NCRIS/AuScope, industry partners and Macquarie University. W. Powell is thanked for his help during the U-Pb acquisitions. A.R. Cruden, B. Bonin and E.C. Ferré are thanked for their constructive comments on an earlier version of this manuscript. C. Archanjo, an anonymous reviewer, the Scientific Editor K. Mezger and the Associate Editors G. Wörner are warmly thanked for their constructive review, help and encouragement.

\section{DATA AVAILABILITY STATEMENT}

The data that support the findings of this study are available from the corresponding author upon reasonable request.

\section{ORCID}

Michel de Saint Blanquat (iD https://orcid.

org/0000-0001-8150-104X

Michel Grégoire iD https://orcid.org/0000-0001-9196-876X

\section{REFERENCES}

Annen, C., Blundy, J. D., Leuthold, J., \& Sparks, R. S. J. (2015). Construction and evolution of igneous bodies: Towards an integrated perspective of crustal magmatism. Lithos, 230, 206-221. https://doi. org/10.1016/j.lithos.2015.05.008

Annen, C., Blundy, J. D., \& Sparks, R. S. J. (2006). The genesis of intermediate and silicic magmas in deep crustal hot zones. Journal of Petrology, 47, 505-539. https://doi.org/10.1093/petrology/egi084

Barboni, M., Annen, C., \& Schoene, B. (2015). Evaluating the construction and evolution of upper crustal magma reservoir with coupled $\mathrm{U} / \mathrm{Pb}$ zircon geochronology and thermal modeling: A case study from the Mt. Capanne pluton (Elba, Italy). Earth and Planetary Science Letters, 432, 436-448.

Barboni, M., Schoene, B., Ovtcharova, M., Bussy, F., Schaltegger, U., \& Gerdes, A. (2013). Timing of incremental pluton construction and magmatic activity in a back-arc setting revealed by ID-TIMS U/Pb and $\mathrm{Hf}$ isotopes on complex zircon grains. Chemical Geology, 340, 76-93. https://doi.org/10.1016/j.chemgeo.2012.12.011

Bonin, B., Ethien, R., Gerbe, M. C., Cottin, J. Y., Feraud, G., Gagnevin, D., ... Moine, B. (2004). The Neogene to Recent Rallier-du-Baty nested ring complex, Kerguelen Archipelago (TAAF, Indian Ocean): Stratigraphy revisited, implications for cauldron subsidence mechanisms. Geological Society, London, Special Publications, 234, 125-149. https://doi.org/10.1144/GSL.SP.2004.234.01.08

Burchardt, S., Tanner, D. C., \& Krumbholz, M. (2010). Mode of emplacement of the Slaufrudalur Pluton, Southeast Iceland inferred from three-dimensional GPS mapping and model building. Tectonophysics, 480, 232-240. https://doi.org/10.1016/j.tecto.2009.10.010
Cannat, M. (1996). How thick is the magmatic crust at slow spreading oceanic ridges? Journal of Geophysical Research, 101, 2847-2857. https://doi.org/10.1029/95JB03116

Charvis, P., Recq, M., Operto, S., \& Brefort, D. (1995). Deep structure of the northern Kerguelen Plateau and hotspot-related activity. Geophysical Journal International, 122, 899-924. https://doi. org/10.1111/j.1365-246X.1995.tb06845.x

Coleman, D. S., Mills, R. D., \& Zimmerer, M. J. (2016). The Pace of Plutonism. Elements, 12, 97-102. https://doi.org/10.2113/gsele ments.12.2.97

Crisp, J. A. (1984). Rates of magma emplacement and volcanic output. Journal of Volcanology and Geothermal Research, 20, 177-211. https:// doi.org/10.1016/0377-0273(84)90039-8

Cruden, A. R. (1998). On the emplacement of tabular granites. Journal of the Geological Society-London, 155, 853-862. https://doi. org/10.1144/gsjgs.155.5.0853

de Saint Blanquat, M., Horsman, E., Habert, G., Morgan, S., Vanderhaeghe, O., Law, R., \& Tikoff, B. (2011). Multiscale magmatic cyclicity, duration of pluton construction, and the paradoxical relationship between tectonism and plutonism in continental arcs. Tectonophysics, 500, 20-33. https://doi.org/10.1016/j.tecto.2009.12.009

de Saint Blanquat, M., Law, R. D., Bouchez, J.-L., \& Morgan, S. S. (2001). Internal structure and emplacement of the Papoose Flat Pluton: An integrated structural, petrographic and magnetic susceptibility study. Geological Society of America Bulletin, 113(8), 976-995. https:// doi.org/10.1130/0016-7606(2001)113<0976:ISAEOT>2.0.CO;2

Dick, H. J. B., Natland, J. H., \& ODP leg 176 Scientific Team. (2000). A long in situ section of the lower ocean crust: results of ODP Leg 176 drilling at the Southwest Indian Ridge. Earth and Planetary Science Letters, 179(1), 31-51. https://doi.org/10.1016/S0012-821X(00)00102-3

Dick, H. J. B., Tivey, M. A., \& Tucholke, B. E. (2008). Plutonic foundation of a slow-spreading ridge segment: Oceanic core complex at Kane Megamullion, 23_300N, 45_200W. Geochemistry, Geophysics, Geosystems, 9, https://doi.org/10.1029/2007GC001645

Farina, F., Dini, A., Innocenti, F., Rocchi, S., \& Westerman, D. S. (2010). Rapid incremental assembly of the Monte Capanne pluton (Elba Island, Tuscany) by downward stacking of magma sheets. Geological Society of America Bulletin, 122(9/10), 1463-1479. https://doi. org/10.1130/B30112.1

Gautier, I., Weis, D., Mennessier, J. P., Vidal, P., Giret, A., \& Loubet, M. (1990). Petrology and geochemistry of the Kerguelen Archipelago basalts (South Indian Ocean), evolution of the mantle sources from ridge to intraplate position. Earth and Planetary Science Letters, 1-3, 59-76. https://doi.org/10.1016/0012-821X(90)90176-X

Gillis, K. M., Snow, J. E., Klaus, A., Abe, N., Adrião, Á. B., Akizawa, N., ... Wintsch, R. P. (2014). and many others, Primitive layered gabbros from fast-spreading lower oceanic crust. Nature, 505, 204-207. https://doi.org/10.1038/nature12778

Giret, A. (1983). Le plutonisme océanique intraplaque: Exemple des lles Kerguelen: Laboratoire de pétrologie, Université Pierre et Marie Curie, CNFRA. Comité National Français Pour Les Recherches Antarctiques, 54, 290.

Glazner, A. F., Bartley, J. M., Coleman, D. S., Gray, W., \& Taylor, R. Z. (2004). Are plutons assembled over millions of years by amalgamation from small magma chambers? GSA Today, 14, 4. https://doi. org/10.1130/1052-5173(2004)014<0004:APAOMO>2.0.CO;2

Grégoire, M., Cottin, J. Y., Giret, A., Mattielli, N., \& Weis, D. (1998). The meta-igneous granulite xenoliths from Kerguelen Archipelago: Evidence of a continent nucleation in an oceanic setting. Contributions to Mineralogy and Petrology, 133, 259-283. https://doi.org/10.1007/ s004100050451

Grégoire, M., Mattielli, N., Nicollet, C., Cottin, J. Y., Leyrit, H., Weis, D., ... Giret, A. (1994). Oceanic mafic granulite xenoliths from the Kerguelen archipelago. Nature, v. 367, 360-363. https://doi. org/10.1038/367360a0 
Hildreth, W., \& Moorbath, S. (1988). Crustal contributions to arc magmatism in the Andes of Central Chile. Contributions to Mineralogy and Petrology, 98, 455-489. https://doi.org/10.1007/BF00372365

Horsman, E., Morgan, S., de Saint-Blanquat, M., Habert, G., Nugent, A., Hunter, R. A., \& Tikoff, B. (2009). Emplacement and assembly of shallow intrusions from multiple magma pulses, Henry Mountains, Utah. Earth and Environmental Science Transactions of the Royal Society of Edinburgh, 100, 117-132. https://doi.org/10.1017/S175569100 9016089

Ildefonse, B., Blackman, D. K., John, B. E., Ohara, Y., Miller, D. J., MacLeod, C. J., \& Integrated Ocean Drilling Program Expeditions 304/305 Science Party. (2007). Oceanic core complexes and crustal accretion at slow-spreading ridges. Geology, 35(7), 623-626. https:// doi.org/10.1130/G23531A.1

Kar, A., Weaver, B., Davidson, J., \& Colucci, M. (1998). Origin of differentiated volcanic and Plutonic rocks from Ascension Island, South Atlantic Ocean. Journal of Petrology, 39, 1009-1024. https://doi. org/10.1093/petroj/39.5.1009

Leuthold, J., Müntener, O., Baumgartner, L. P., Putlitz, B., Ovtcharova, M., \& Schaltegger, U. (2012). Time resolved construction of a bimodal laccolith (Torres del Paine, Patagonia). Earth and Planetary Science Letters, 325-326, 85-92. https://doi.org/10.1016/j.epsl.2012.01.032

Nougier, J. (1969). Contribution à l'étude géologique etgéomorphologique des îles Kerguelen: CNFRA. Comité National Français Pour les RecherchesAntarctiques, 27, 2, 422 pp..

Padilla, A. J., Miller, C. F., Carley, T. L., Economos, R. C., Schmitt, A. K., Coble, M. A., ... Hanchar, J. M. (2016). Elucidating the magmatic history of the Austurhorn silicic intrusive complex (southeast Iceland) using zircon elemental and isotopic geochemistry and geochronology. Contributions to Mineralogy and Petrology, 171, 1-21. https://doi. org/10.1007/s00410-016-1279-z

Paterson, S. R., \& Ducea, M. N. (2015). Arc magmatic tempos: Gathering the evidence. Elements, 11(2), 91-98. https://doi.org/10.2113/gsele ments.11.2.91

Petford, N., Cruden, A. R., McCaffrey, K. J., \& Vigneresse, J.-L. (2000). Granite magma formation, transport and emplacement in the Earth's crust. Nature, 408, 669-673. https://doi.org/10.1038/35047000

Ponthus, L. (2018). Origine, évolution et mise en place d'un pluton alcalin récent en contexte intraplaque océanique. Exemple du complexesud de Rallier du Baty, Kerguelen (T.A.A.F.).PhD thesis, Toulouse University, $277 \mathrm{pp}$.

Rocchi, S., Westerman, D. S., Dini, A., Innocenti, F., \& Tonarini, S. (2002). Two-stage growth of laccoliths at Elba Island, Italy. Geology, 30(11), 983-986. https://doi.org/10.1130/0091-7613(2002)030<0983:TSGOLA>2.0.CO;2

Shaw, H. R. (1985). Links between magma-tectonic rate balances, plutonism, and volcanism. Journal of Geophysical Research, 90, 1127511288. https://doi.org/10.1029/JB090iB13p11275

Watkins, N. D., Gunn, B. M., Nougier, J., \& Baksi, A. K. (1974). Kerguelen: Continental fragment or oceanic island? Geological Society of America Bulletin, 85, 201-212. https://doi. org/10.1130/0016-7606(1974)85<201:KCFOOI>2.0.CO;2

White, S. M., Crisp, J. A., \& Spera, F. J. (2006). Long-term volumetric eruption rates and magma budgets. Geochemistry, Geophysics, Geosystems, 7, https://doi.org/10.1029/2005GC001002

Widom, E., Gill, J. B., \& Schmincke, H.-U. (1993). Syenite nodules as a long-term record of magmatic activity in Agua de Pao Volcano,
Sao Miguel, Azores. Journal of Petrology, 34, 929-953. https://doi. org/10.1093/petrology/34.5.929

\section{SUPPORTING INFORMATION}

Additional supporting information may be found online in the Supporting Information section.

Figure S1. Simplified geological map of Kerguelen Archipelago highlighting the different magmatic series intruding the flood basalts, the orientation of the latter (from Nougier, 1969) and the previous datings published (adapted from Nicolaysen et al., 2000) on the intrusive rocks.

Figure S2. Geometry of the basalt lava flows, at the W (a), NE (b), and $\mathrm{S}$ (c) of the SRBIC; (d) locations are displayed on (d) the topographic map of Kerguelen (IGN).

Figure S3. Sharp low dipping magmatic contact between the Unit 2 and 3 on the Massif des Deux Frères.

Figure S4. Maps and stereographic projections of field measurements of: magmatic layering (a), cataclastic shear zones (b). Due to resolution issues all the single measurements are not reported here and mean-vectors were used in several locations for easier lecture without loss of information.

Figure S5. Outcrops showing syn-plutonic shear-zones activity in the SRBIC: a/ a first generation of south-dipping cataclastic shear zones (1) cross-cut the syenite, a pegmatitic dyke (2) cross-cut this first generation of cataclastic shear zones, and a late generation of cataclastic shear zones (3), dipping to the south with a lower angle than the first generation, cross-cut all the previous structures.

Figure S6. Examples of zircon morphologies separated from the plutonic rocks of the SRBIC.

Figure S7 and Table S2. Synthetic histogram and list of the U-Pb datings acquired on the SRBIC (2_ errors), sorted within each unit by progressive age.

Table S1. Published geochronological data on the Rallier du Baty plutonic province.

Table S3. Zircon U-Pb ages data from the SRBIC, Kerguelen archipelago (T.A.A.F).

Table S4. Samples geographic coordinates.

Data S1. Methodology.

How to cite this article: Ponthus L, de Saint Blanquat M, Guillaume D, et al. Plutonic processes in transitional oceanic plateau crust: Structure, age and emplacement of the South Rallier du Baty laccolith, Kerguelen Islands. Terra Nova. 2020;00:1-7. https://doi.org/10.1111/ter.12471 